\title{
Mathematical Representation Ability of Middle School Students through Model Eliciting Activities with STAD Type
}

\author{
Zairisma1, Vina Apriliani ${ }^{1 *}$, Johan Yunus ${ }^{2}$ \\ 1 UIN Ar-Raniry Banda Aceh, Indonesia \\ 2 Universitas Syiah Kuala, Indonesia
}

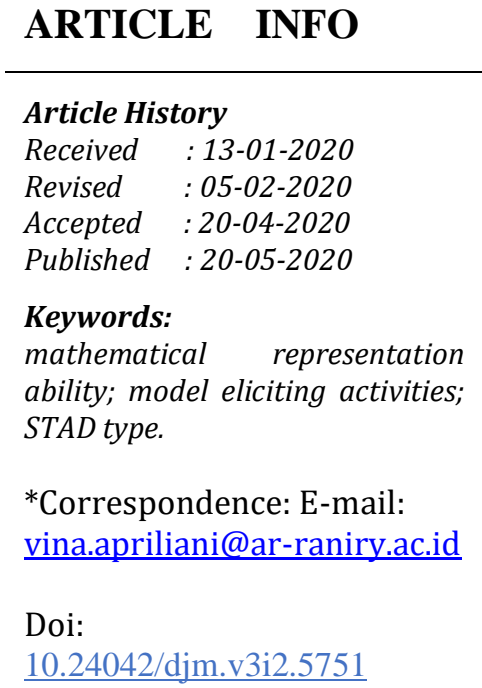

\section{ARTICLE INFO}

\section{Article History}

10.24042/djm.v3i2.5751

\begin{abstract}
The ability of mathematical representation is one of the abilities that must be possessed by students in learning mathematics. In fact, students 'mathematical representation ability is still relatively low, so we need a learning model that can improve students' mathematical representation abilities, namely Model Eliciting Activities (MEA) with STAD type. The purpose of this study is to compare the mathematical representation ability of students taught using MEA with STAD type and those taught with conventional learning. The approach to be used is a quantitative approach with a quasiexperimental research method and using a control group pretest-posttest design. The population in this study were all VII grade students. Sampling was done using simple random sampling, which consisted of two classes, class $\mathrm{VII}_{1}$ as the experimental class and class $\mathrm{VII}_{2}$ as the control class. Data collection is used by using a mathematical representation ability test sheet. The data analysis technique used is independent $t$-test. Based on these analysis it can be concluded that the mathematical representation ability of students taught using MEA with STAD type is better than conventional learning.
\end{abstract}

http://ejournal.radenintan.ac.id/index.php/desimal/index

\section{INTRODUCTION}

National Council Teacher of Mathematics (NCTM) 2016 sets out some of the mathematical abilities students need to have to face problems, both in mathematics and in real life. One of the mathematical abilities that must be mastered by students is the mathematical representation ability which is the fifth ability on the NCTM standards in 2016. The ability of this representation can be said to be the ability of the way of thinking that students must possess to overcome mathematical problems and express their solutions (Surya \& Yulia, 2017). Forms of 
student interpretation can be in the form of words or verbal, written, drawing, tables, graphs, concrete objects, mathematical symbols and others (Sabirin, 2014). In other words, the ability of representation is the ability of students to communicate problem ideas in the form of other interpretations such as graphs, tables, pictures and so forth.

Based on these descriptions, the ability of mathematical representation is very necessary for solving mathematical problems. But the fact is the representation ability of students in solving problems is still very low. The low ability of mathematical representation can be seen in the results of TIMSS (Trends in International Mathematics and Science Study) and PISA (Programme for International Student Assessment). According to the 2015 TIMSS results, Indonesia ranks 46th out of 51 countries and the 2018 PISA score used to assess 15year-old school students shows that Indonesia ranks 72 th out of 78 countries. The same thing can also be seen from the results of the 2019 mathematics national examination in Aceh which is still below the national average of 45.52, Aceh only scored 38.79. This value is the second lowest value of all provinces in Indonesia. From the results of the national examination, it can be seen that the mathematical abilities of Acehnese students are still not optimal. As for the questions that were tested at TIMSS, PISA, and national examination, included mathematical literacy problems, one of which also contained mathematical representations.

Based on previous research, there are various kinds of learning models that have been used to improve students' mathematical representation abilities (Effendi, 2012; Farhan \& Retnawati, 2014; Hernawati, 2016; Hutagaol, 2013; Muhamad, 2017; Murni, 2014; Nahdi, 2017; Sulastri, Marwan, \& Duskri, 2017; Wahyuni, 2012; Yusnita, Maskur, \&
Suherman, 2016). One learning model used to improve students' mathematical representation ability is the Model Eliciting Activities (MEA) combined with STAD (Student Teams Achievement Division) type learning (Afri \& Widyastuti, 2019; Rianti, Arcat, \& Afri, 2016). The characteristic of MEA is that MEA can raises a real problem, so students will more easily associate abstract mathematical concepts. Thus students will be more interested and active to solve the problems that have been given. MEA also encourages students to make a mathematical model which will then be constructed in another form. Whereas STAD type learning is a very simple cooperative learning which is considered to be able to support learning more actively.

With the combination of MEA syntax with the STAD type, students are expected to be more active in learning so that ideas in students' thoughts will be channeled and more enthusiastic in learning because in the STAD type there is a phase of giving awards for students who are considered active during the teaching-learning process take place. Awards given by teachers can also make students more motivated to learn. Therefore, MEA learning with STAD type is expected to improve students' mathematical representation ability.

This is reinforced by several researchers who have studied the ability of mathematical representation using MEA learning or STAD type. In research with MEA learning (Afri \& Widyastuti, 2019; Hanifah, 2015; Lestari \& Hanifah, 2018; Pratiwi, 2013), it can be concluded that the achievement and improvement of the mathematical representation ability of students who get MEA learning are better than students who get conventional learning. Then in research with STAD type learning (Alvanisa, 2019; Dewi, 2017; Maesaroh, 2013; Mufidati, 2019; Rianti et al., 2016; Subchan, 2019; Suprapto, 2015; 
Wardani, Jamiah, \& Ijuddin, 2015) show that the mathematical representation ability of students with the STAD type is better than conventional learning.

Based on the explanation and relevant research regarding the problems that have been described above, then we are interested in combining the two learning models, namely Model Eliciting Activities (MEA) with the type of Student Teams Achievement Division (STAD). The purpose of this study is to compare the mathematical representation abilities of students taught using MEA with STAD types and those taught with conventional learning.

\section{METHODS}

In this study, the approach that researchers used was a quantitative approach. This research will use a quasiexperiment where the sample design is an ordinary class without changing the existing structure (Sanjaya, 2013).

This research was conducted at Babahrot 1 State Middle School located at Meulaboh-Tapaktuan National Road, Pantee Rakyat, Southwest Aceh District. The study population was all grade VII students of Babahrot 1 State Middle School. The sampling method is done by the simple random sampling method by taking two classes randomly. The sample in this study were two classes from class VII of Babahrot 1 State Middle School which had the same initial ability, namely class VII ${ }_{1}$ as the experimental class and $\mathrm{VII}_{2}$ as the control class.

The type of design that will be used is the pretest-posttest control group design. This design uses two classes that will serve as the control class and the experimental class chosen at random. Then to determine the initial ability, the sample will be given a pre-test (Trianto, 2012). The pre-test results will be good if the values of the two classes do not differ significantly. The research design can be seen in Table 1 (Sugiono, 2010).

Table 1. The Research Design

\begin{tabular}{|c|c|c|c|}
\hline Class & $\begin{array}{l}\text { Pre- } \\
\text { test }\end{array}$ & Treatment & $\begin{array}{c}\text { Post- } \\
\text { test }\end{array}$ \\
\hline Experiment & $\mathrm{O}_{1}$ & $\mathrm{X}$ & $\mathrm{O}_{2}$ \\
\hline Control & $\mathrm{O}_{1}$ & $\mathrm{Y}$ & $\mathrm{O}_{2}$ \\
\hline
\end{tabular}

Information:

$\mathrm{X}=$ Learning using MEA with STAD type

$\mathrm{Y}=$ Learning using conventional learning

$\mathrm{O}_{1}=$ Pre-test of the experimental class and the control class

$\mathrm{O}_{2}=$ Post-test of the experimental class and the control class

The instruments that we use to collect data on this research are learning tools (RPP, LKPD, etc.) and test sheets containing pre-test and post-test questions arranged in the form of essays to measure students' mathematical representation abilities. The research instruments were validated by experts (lecturers and teachers). The scoring guidelines that we took in this study to assess students' pre-test and post-test answers are the guidelines for scoring mathematical representation abilities that can be seen in the following Table 2 (Sulastri et al., 2017). 
Desimal, 3 (2), 2020 - 112

Zairisma, Vina Apriliani, Johan Yunus

Table 2. Guidelines for Scoring Mathematical Representation Abilities

The observed aspect

Present data or information from a problem to the representation of images, diagrams, graphs, or tables

Solve problems involving mathematical expressions

Write the steps in solving mathematical problems in words

\section{Indicator}

No data or information is presented to represent images, diagrams, graphs, or tables

Data or information that can be presented to the representation of images, diagrams, graphs, or tables is incorrect

Present data/information to represent images, diagrams, 2 graphs, or tables is almost correct

Present data/information to the correct representation of 3 images, diagrams, graphs, or tables

There is no problem solving that involves a mathematical 0 expression

Solve problems that involve mathematical expressions but 1 wrong solutions

Solve problems that involve mathematical expressions but the solution is less correct

Solve problems involving mathematical expressions 3 correctly

No explanation

Just a little explanation (only known and asked) 1

Mathematical explanation but not logically arranged 2

Mathematical explanation clearly and logically arranged
Data collection that we use to obtain data in this study is a test. In this case, we will use 2 tests in the form of essay. The test is a pre-test containing two essay questions conducted at the beginning of learning with the aim of seeing students' initial mathematical representation abilities. Furthermore, the post-test contains two essay questions conducted at the end of learning with the aim of seeing students' mathematical representation abilities after the implementation of MEA with STAD type.

To analyze the research data, the following calculations are made:

1. Analysis of Mathematical Representation Ability Tests

a. Convert ordinal data into interval data using the MSI (Method of Successive Interval) as a condition for hypothesis testing.

b. Normality test uses the chi-square formula to see whether the research data is normally distributed or not. c. Homogeneity test uses the F test to find out whether the sample from this study has the same variance or not.

d. Hypothesis testing uses t-test to see whether the mathematical representation ability of students taught using MEA learning with STAD type is better than conventional learning.

2. Percentage of achievement of each indicator of students' mathematical representation ability using formulas:

Information:

$$
P=\frac{f}{N} \times 100 \%
$$

$$
\begin{aligned}
\mathrm{P}= & \begin{array}{l}
\text { Percentage of students' } \\
\text { mathematical representation } \\
\text { abilities of each indicator }
\end{array} \\
\mathrm{f}= & \begin{array}{l}
\text { Frequency of each aspect of } \\
\text { observation }
\end{array} \\
\mathrm{N}= & \text { Number of frequencies }
\end{aligned}
$$

\section{RESULTS AND DISCUSSIONS}


Desimal, 3 (2), 2020 - 110

Zairisma, Vina Apriliani, Johan Yunus

The results of students' mathematical representation ability in the experimental class and the control class

after being converted into interval scale data can be seen in the following Table 3.

Table 3. The Results of Mathematical Representation Ability of Experimental Class and Control Class

\begin{tabular}{lccccc}
\hline \multicolumn{1}{c}{ Class } & Mini-mum & $\begin{array}{c}\text { Score } \\
\text { Maxi-mum }\end{array}$ & Ave-rage & $\begin{array}{c}\text { Variance } \\
\left(\boldsymbol{s}^{2}\right)\end{array}$ & $\begin{array}{c}\text { Stan-dard } \\
\text { devia-tion }\end{array}$ \\
Experi-ment & 12,87 & 19,45 & 16,2 & 1,99 & 1,413 \\
Control & 11,96 & 17,60 & 14,1 & 2,03 & 1,425 \\
\hline
\end{tabular}

Based on the results of the normality test, it was concluded that the mathematical representation ability of students in the experimental class and the control class came from the normal distribution population. In addition, the homogeneity test shows that there is no difference in the data variance of students' mathematical representation abilities between the experimental class and the control class.

After the prerequisite test results are met (normality test and homogeneity test), then proceed with the hypothesis test using t-independent test (two-party test). The results obtained are $t_{\text {count }}>$ $t_{\text {table }}$ which is $5,049>1,675$. Based on the criteria, it can be decided that $\mathrm{H}_{0}$ is rejected, then $\mathrm{H}_{1}$ is accepted. Therefore it can be concluded that the mathematical representation ability of students taught by the Model Eliciting Activities (MEA) with the STAD type is better than that taught by conventional learning.

The comparison of the two classes will be clearly seen when presented as a percentage based on indicators of students' mathematical representation abilities. Comparison of the percentage of post-test scores of the experimental class and the control class is in Table 4.

Table 4. Percentage Score Results of Post-test Mathematical Representation Ability of Students

\begin{tabular}{clcc}
\hline \multicolumn{4}{c}{ Experimental Class } \\
No. & $\quad$ The observed aspect & Low & High \\
1 & Visual Representation & $17 \%$ & $83 \%$ \\
2 & Symbolic Representation & $14 \%$ & $86 \%$ \\
3 & Verbal Representation & Control Class & \\
& $\quad$ The observed aspect & Low & High \\
No. & Visual Representation & $32 \%$ & $68 \%$ \\
1 & Symbolic Representation & $32 \%$ & $68 \%$ \\
3 & Verbal Representation & $34 \%$ & $66 \%$ \\
\hline
\end{tabular}

Based on Table 4 above, it can be seen that the overall mathematical representation ability score of students in the experimental class is very different from the mathematical representation ability of students in the control class. This is evidenced by the differences seen from each indicator of students' mathematical representation ability.
In the visual representation indicator in the experimental class, those who met the high criteria were $83 \%$ and low by $17 \%$, while in the control class that met the high criteria by $68 \%$ and low by $32 \%$. In the symbolic representation indicator in the experimental class, those who meet the high criteria are $86 \%$ and low by $14 \%$, while the control class that 
meets the high criteria is $68 \%$ and low by $32 \%$. Then the verbal representation indicator in the experimental class, which meets the high criteria by $79 \%$ and low by $21 \%$, while in the control class that meets the high criteria by $66 \%$ and low by $34 \%$. So it can be concluded that the mathematical representation ability of students taught using MEA with STAD type is better than those taught with conventional learning.

Based on the results of the hypothesis test, it can be concluded that the mathematical representation ability of students taught using the Model Eliciting Activities (MEA) with the STAD type is better than that taught with conventional learning.

This can also be seen from the initial steps of providing motivation and learning objectives, students will be more motivated and understand the purpose he is studying the material. MEA with STAD type makes it easier for students to represent problems given by the teacher in other forms. This is because in one of the learning steps of MEA with STAD type there is an activity to find a mathematical model (initial). So in this step, students are more motivated and can put out the ideas contained in these students. The problem given by the teacher is a real problem that exists in the daily lives of students. Thus, students will be more focused, interested and not feel bored when learning takes place.

In addition, at a later stage that can make the ability of representation increase after being taught using MEA with the STAD type is the use of models that students have found in the initial problem to the advanced problem given by the teacher. In this step, students can practice the ability of visual representation, symbolic representation, and verbal representation of students. After finding the right mathematical model, students will find it easier to interpret the model in other forms, such as graphs, tables, pictures, diagrams, and writing/words.

In MEA with STAD type, there are also presentations that will be represented by representatives of each group. The presentation will make students more active. After the presentation, the group that scores the best and is most active in the question and answer discussion will be given an award from the teacher. With these prizes, students will be more active in participating in ongoing learning.

The results of this study are in accordance with the results of previous studies which said that the mathematical representation ability of students who obtained MEA learning or learning with STAD type was better than students who obtained conventional learning. The difference between this research and previous research is that this study uses a combination of two learning models namely MEA and STAD type cooperative models. Combining these two models gives a similar result which can improve students' mathematical representation ability better than conventional learning.

\section{CONCLUSIONS AND SUGGESTIONS}

Based on the results of research on learning mathematics using Model Eliciting Activities (MEA) with STAD type on the mathematical representation ability of middle school students, it is concluded that the mathematical representation ability of students taught using MEA with STAD type is better than the ability representations of students taught by conventional learning. This can be one alternative to learning mathematics that can be applied by teachers in schools.

\section{REFERENCES}

Afri, L. D., \& Widyastuti. (2019). Penerapan pembelajaran modeleliciting activities (MEAs) terhadap kemampuan representasi siswa SMP. Jurnal Ilmiah Edu Research, 8(1), 22- 
Desimal, 3 (2), 2020 - 115

Zairisma, Vina Apriliani, Johan Yunus

28.

Alvanisa, P. (2019). Analisis Kemampuan Representasi Matematika Siswa pada Pembelajaran Kooperatif Tipe STAD di MTs Negeri 2 Medan. (Doctoral Dissertation, Universitas Negeri Medan).

Dewi, A. (2017). Pengembangan Perangkat Pembelajaran Berbasis Pembelajaran Kooperatif Tipe STAD untuk Meningkatkan Kemampuan Representasi Matematik di MTs Swasta Cerdas Murni Tembung. (Doctoral Dissertation, UNIMED).

Effendi, L. A. (2012). Pembelajaran matematika dengan metode penemuan terbimbing untuk meningkatkan kemampuan representasi dan pemecahan masalah matematis siswa SMP. Jurnal Penelitian Pendidikan, 13(2), 1-10.

Farhan, M., \& Retnawati, H. (2014). Keefektifan PBL dan IBL ditinjau dari prestasi belajar, kemampuan representasi matematis, dan motivasi belajar. Jurnal Riset Pendidikan Matematika, 1(2), 227-240.

Hanifah, H. (2015). Penerapan pembelajaran model eliciting activities (MEA) dengan pendekatan saintifik untuk meningkatkan kemampuan representasi matematis siswa. Kreano, Jurnal Matematika Kreatif-Inovatif, 6(2), 191-198.

Hernawati, F. (2016). Pengembangan perangkat pembelajaran matematika dengan pendekatan PMRI berorientasi pada kemampuan representasi matematis. Jurnal Riset Pendidikan Matematika, 3(1), 34-44.

Hutagaol, K. (2013). Pembelajaran kontekstual untuk meningkatkan kemampuan representasi matematis siswa sekolah menengah pertama. Infinity Journal, 2(1), 85-99.

Lestari, I. A., \& Hanifah. (2018).
Peningkatan kemampuan representasi matematis serta self confidence siswa SMP dengan menggunakan model eliciting activities (MEA). In Seminar Nasional Matematika dan Pendidikan Matematika (Sesiomadika) (pp. 459468).

Maesaroh, E. (2013). Peningkatan Kemampuan Representasi dan Komunikasi Matematik melalui Pembelajaran Kooperatif Student Teams Achievement Divisions (STAD) Berbantuan Program Cabri 3D pada Siswa Sekolah Menengah Atas. (Doctoral Dissertation, UNPAS).

Mufidati, L. I. (2019). Efektivitas Coopertaive Learning Tipe STAD untuk Meningkatkan Kemampuan Representasi Matematis Peserta Didik di Kelas $V$ MI Ma'Arif NU 01 Karangklesem, Pekuncen, Banyumas. (Doctoral Dissertation, IAIN Purwokerto).

Muhamad, N. (2017). Pengaruh metode discovery learning untuk meningkatkan representasi matematis dan percaya diri siswa. Jurnal Pendidikan UNIGA, 10(1), 9-22.

Murni, A. (2014). Peningkatan kemampuan representasi matematis siswa SMP melalui pembelajaran metakognitif dan pembelajaran metakognitif berbasis soft skill. Jurnal Pendidikan, 4(2), 96-107.

Nahdi, D. S. (2017). Implementasi model pembelajaran collaborative problem solving Untuk meningkatkan kemampuan representasi matematis siswa sekolah dasar. Jurnal Cakrawala Pendas, 3(1).

Pratiwi, D. E. (2013). Penerapan Pendekatan Model Eliciting Activities (MEAs) untuk Meningkatkan Kemampuan Representasi Matematis Siswa SMP. (Doctoral Dissertation, Universitas Pendidikan Indonesia). 
Desimal, 3 (2), 2020 - 116

Zairisma, Vina Apriliani, Johan Yunus

Rianti, R., Arcat, \& Afri, L. E. (2016). Pengaruh model pembelajaran kooperatif tipe student teams achievement divisions (STAD) terhadap kemampuan representasi matematis siswa kelas VIII SMP Muhamadiyah Pasir Pengaraian. Jurnal Ilmiah Mahasiswa FKIP Universitas Pasir Pengaraian, 2(2), 14.

Sabirin, M. (2014). Representasi dalam pembelajaran matematika. Jurnal Pendidikan Matematika IAIN Antasari, 1(2).

Sanjaya, W. (2013). Penelitian Pendidikan: Jenis, Metode dan Prosedur. Jakarta: Kencana.

Subchan, A. (2019). Model pembelajaran kooperatif tipe student team achievement divisions (STAD) terhadap kemampuan representasi matematis siswa kelas VIII SMPN 2 Tambusai Utara. Jurnal Absis, 2(1), 104-111.

Sugiono. (2010). Metode Penelitian Pendidikan. Bandung: CV Alfabeta.

Sulastri, S., Marwan, M., \& Duskri, M. (2017). Kemampuan representasi matematis siswa SMP melalui pendekatan pendidikan matematika realistik. Beta: Jurnal Tadris Matematika, 10(1), 51-69.

Suprapto. (2015). Pengaruh model pembelajaran kooperatif tipe STAD terhadap peningkatan kemampuan representasi dan pemecahan masalah matematis siswa. Indonesian Digital
Journal of Mathematics and Education, 2(3), 154-164.

Surya, E., \& Yulia, N. (2017). Kemampuan Representasi Matematis Siswa pada Pembelajaran Matematika. Medan: State University of Medan.

Trianto. (2012). Mendesain Model Pembelajaran Inovatif-Progresif: Konsep, Landasan, dan Implementasinya pada Kurikulum Tingkat Satuan Pendidikan (KTSP). Jakarta: Kencana Prenada Media Group.

Wahyuni, S. (2012). Peningkatan Kemampuan Representasi Matematis dan Self Esteem Siswa Sekolah Menengah Pertama dengan Menggunakan Model Pembelajaran ARIAS. (Doctoral Dissertation, Universitas Pendidikan Indonesia).

Wardani, T., Jamiah, Y., \& Ijuddin, R. (2015). Penerapan model pembelajaran kooperatif tipe STAD untuk meningkatkan kemampuan representasi matematis materi program linear. Jurnal Pendidikan Dan Pembelajaran Khatulistiwa, 4(1).

Yusnita, I., Maskur, R., \& Suherman, S. (2016). Modifikasi model pembelajaran Gerlach dan Ely melalui integrasi nilai-nilai keislaman sebagai upaya meningkatkan kemampuan representasi matematis. Al-Jabar: Jurnal Pendidikan Matematika, 7(1), 29-38. 